\title{
Correction to: Patient's awareness on COPD is the strongest predictor of persistence and adherence in treatment-naïve patients in real life: a prospective cohort study
}

Elsa López-Pintor ${ }^{1,2}$, Justo Grau ${ }^{3}$ and Blanca Lumbreras ${ }^{2,4^{*}}$ (1)

\section{Correction to: BMC Pulmonary Medicine (2021) 21:388} https://doi.org/10.1186/s12890-021-01754-6

Following publication of the article [1], the authors flagged that the first and last names of the authors had been erroneously swapped in the author list.

The author list has since been corrected in the published article and the corrected author list may be seen in this correction.

\section{Publisher's Note}

Springer Nature remains neutral with regard to jurisdictional claims in published maps and institutional affiliations.

\section{Author details}

'Department of Engineering, Area of Pharmacy and Pharmaceutical Technologies, Miguel Hernández University, Crtra Alicante-Valencia km 81, Sant Joan d'Alacant, 03550 Alicante, Spain. ${ }^{2}$ CIBER en Epidemiología y Salud Pública, Madrid, Spain. ${ }^{3}$ Pneumology Department, General Hospital of Elche, Alicante, Spain. ${ }^{4}$ Department of Public Health History of Science and Gynaecology, Miguel Hernández University, Crtra Alicante-Valencia km 81, Sant Joan d'Alacant, 03550 Alicante, Spain.

Published online: 07 March 2022

\section{Reference}

1. Elsa L-P, Justo G, Blanca L. Patient's awareness on COPD is the strongest predictor of persistence and adherence in treatment-naïve patients in real life: a prospective cohort study. BMC Pulm Med. 2021;21:388. https:// doi.org/10.1186/s12890-021-01754-6.

*Correspondence: blumbreras@umh.es

${ }^{2}$ CIBER en Epidemiología y Salud Pública, Madrid, Spain

Full list of author information is available at the end of the article

(c) The Author(s) 2022. Open Access This article is licensed under a Creative Commons Attribution 4.0 International License, which permits use, sharing, adaptation, distribution and reproduction in any medium or format, as long as you give appropriate credit to the original author(s) and the source, provide a link to the Creative Commons licence, and indicate if changes were made. The images or other third party material in this article are included in the article's Creative Commons licence, unless indicated otherwise in a credit line to the material. If material is not included in the article's Creative Commons licence and your intended use is not permitted by statutory regulation or exceeds the permitted use, you will need to obtain permission directly from the copyright holder. To view a copy of this licence, visit http://creativecommons.org/licenses/by/4.0/ The Creative Commons Public Domain Dedication waiver (http://creativeco mmons.org/publicdomain/zero/1.0/) applies to the data made available in this article, unless otherwise stated in a credit line to the data. 